\title{
Unbonded Post Tensioned Concrete Slabs in Fire - Part I - Experimental Response of Unbonded Tendons under Transient Localized Heating
}

\author{
John Gales ${ }^{1}$, Luke A Bisby ${ }^{2}$ and Martin Gillie ${ }^{3}$ \\ ${ }^{1}$ PhD Candidate <j.gales@ed.ac.uk> \\ ${ }^{2}$ Reader, Ove Arup Foundation/RAEng Senior Research Fellow in Structures in Fire <luke.bisby@ed.ac.uk> \\ ${ }^{3}$ Lecturer $<$ m.gillie@ed.ac.uk $>$ \\ ${ }^{1,2,3}$ BRE Centre for Fire Safety Engineering, University of Edinburgh, King's Buildings, Mayfield Road, Edinburgh, UK EH9 3JL
}

\begin{abstract}
The fire-safe structural design and construction of unbonded post-tensioned (UPT) flat plate concrete structures has recently come under debate in the UK, and questions are being raised regarding the response to fire of post-tensioned concrete slabs. Related to these concerns is the real world response of continuous UPT tendons inside such structures both during and after a fire, which is largely unknown and depends on many potentially important factors which are not currently accounted for in standard fire tests. Several credible concerns exist for UPT concrete structures in fire, most notably the potential for premature tendon rupture due to localized heating which may result from a number of possible causes (discussed herein). The research presented in this paper deals specifically with the time-temperature-stress-strength interdependencies of stressed UPT tendons under localized transient heating, as may be experienced by tendons in a real UPT building in a real fire. Nineteen high temperature stress relaxation tests on UPT tendons of realistic length and parabolic longitudinal profile are reported. It is shown that localized heating of UPT tendons is likely to induce premature tendon rupture during fire, even in structures which meet the prescriptive concrete cover requirements imposed by available design codes.
\end{abstract}

Key words: Prestressing steel; Post-tensioned slabs; Unbonded construction; Fire endurance testing; Spalling; Concrete; Concrete cover; High temperature creep; Stress relaxation 


\section{INTRODUCTION}

Unbonded post-tensioned (UPT) concrete structures contain cold-drawn, high strength steel prestressing tendons which are highly stressed (usually to between 800 and $1200 \mathrm{MPa}$ ) under service loads [1]. This type of construction is increasingly favoured in the design of multi-storey office and residential concrete slab construction. Advantages include: increased allowable span to depth ratios with excellent control of deflections, which allows for large, open floor plates; and efficient and rapid construction, which reduces costs and is attractive to developers. Unbonded tendons typically run continuously across multiple bays of a UPT structure and are free to move longitudinally within a duct cast inside the concrete. Localized damage to a tendon (whether due to fire, corrosion, etc) in one bay will therefore affect prestress levels, and hence flexural and shear capacity, across several bays. This behaviour was clearly shown in a large uncontrolled fire that occurred over several floors in a 12 storey UPT condominium building in Key Biscayne, Florida in 2000 [2]. The building contained UPT tendons that were continuous across seven interior bays. Release of tension in the tendons occurred due to fire, which "triggered progressive failure of the post-tensioned slab well beyond the zone of visible damage." The result was that "almost half the slabs on levels three to six, and possibly seven, lost integrity" [2]. This represents 48 bays of the structure losing structural integrity. No contractor could be found who would re-shore the floor slabs after the fire as the risk of progressive collapse was deemed to be sufficiently high, and the building was demolished.

A key benefit of UPT structures, as is widely quoted within the UPT industry, is their 'inherent fire resistance'. This inherent fire resistance is assumed predominantly on the basis of limited (and largely outdated) standardized furnace tests on isolated UPT structural members and assemblies, and is ensured during design simply by prescribing a given overall slab thickness and minimum concrete cover for thermal insulation of the prestressing tendons.

Standardized structural fire resistance testing has many acknowledged inadequacies [3], such as the absence of a cooling phase, the testing of isolated, often simply-supported, and non-continuous elements, and so on. Although numerous standardized tests [4-12] have been performed on UPT concrete structures dating back to the 1950s, no fire experiments have yet been designed to explicitly and rationally investigate the realistic fire performance of a continuous UPT slab, nor have any of the available tests accounted for the critical factor that the tendons in UPT structures are unbonded and continuous over multiple bays, many of which may be distant from the fire-exposed spans.

There has recently been considerable debate in the UK over the fire safety of post-tensioned concrete slabs [3,13], demonstrating that uncertainty as to their response in fire remains. The current paper deals specifically with the issue of transient localized heating of stressed, unbonded tendons which are continuous over multiple bays of a structure; this was identified in a detailed literature previously presented by the authors [14] as never having been explicitly and rationally investigated in available research on the fire performance of UPT slabs. On the basis of this previous detailed review of available test data and case studies of real fires in UPT buildings, Gales et al. [14] concluded that current prescriptive structural fire design guidance does appear to be defensible for preventing structural collapse in isolated simply supported standard furnace tests, particularly in the absence of explosive cover spalling. However, multiple case studies and some of the available test data provide compelling evidence that the available tests cannot predict the response of real UPT buildings in fire, particularly with respect to tendon rupture under localized heating.

For instance, concrete spalling of some form has occurred in all known real fires in UPT buildings, and in two thirds of these cases premature tendon rupture occurred as a consequence [2,15-19]. Spalling has occurred in at least 16 of the 27 available standard furnace tests on UPT elements. Tendon rupture or release of prestress occurred in two thirds of the case studies, confirming that tendon rupture is likely to occur in a real UPT building in a real fire. This has led to both partial and progressive failure of real UPT structures during fires. Tendon rupture has been observed in at least 9 of the 27 available furnace tests, and has been particularly evident in tests with multiple spans and local heating; tendon rupture is more likely in a real building than in a furnace test. Tendon rupture was reported in all eight furnace tests reported by VanHerberghen and VanDamme in 1983 [10]; these tests apparently influenced the development of the Eurocode 2 prescriptive requirements [20], but have been essentially ignored by North American design requirements (such as the International Building Code [21]).

Under localized heating UPT tendons may rupture due to a combination of high temperature creep strains (which accelerate beyond $300^{\circ} \mathrm{C}$ causing high relaxation of prestress), elastic modulus reductions, and loss of ultimate strength. Localized heating may occur in a real structure due to a single bay fire in a continuous multi-bay structure, a travelling fire (such as observed in Building 7 of the World Trade Centre 
complex [22]), a localized ceiling jet fire (particularly in parking structures [23]), spalling of the concrete cover (which is more likely for modern concretes and pre-compressed elements), and longitudinal and transverse cracking during heating (which has been observed in many fire tests and real fires with UPT construction [14]). With respect to current standard furnace testing procedures for UPT concrete slabs, there are two fundamental inadequacies relevant to this discussion:

1) The total anchor-to-anchor length of UPT tendons in standard furnace tests is always much shorter than in real UPT structures. An isolated component test can not capture the behaviour of an isolated compartment fire where the tendon will be locally heated.

2) Standard furnace tests are, by definition and by design, intended to provide as uniform a heating as possible to the tested assembly, thus minimizing localization of heating. In a real fire, in an open plan building, the heating may be spatially non-uniform, travelling, and/or localized [24,25].

Both inadequacies can result in standardized testing being unconservative with respect to tendon rupture due to localized heating of the tendon.

Whatever the cause of localized heating of a UPT tending, it is clear that a better understanding of the potential consequences of this on tendon response is needed to ensure fire safe design and construction of UPT buildings. Since full scale tests on model or actual UPT multi bay concrete structures, even though badly needed, are unlikely within the future, research is currently restricted to using targeted experiments and computational analysis tools [26,27]. Analysis tools, however, have not yet been sufficiently validated against real concrete structures in fire, and their ability to model the transient behaviour of unbonded tendons, and discrete cracking and shear failure of concrete, at elevated temperature remains questionable. This is Part I of a two-part paper focusing on the structural fire performance of modern flat-plate UPT concrete structures in an effort to establish, both experimentally and computationally, the potential consequences of localized heating of UPT tendons during fire, with a view to eventually developing the ability to defensibly model full UPT buildings in fire. Part I provides a detailed summary of the results of 19 transient high temperature prestress relaxation and rupture tests on restrained unbonded tendons exposed to various localized heating regimes. The potential consequences of localized heating are discussed. Part II presents, validates, and uses a computational heat transfer and prestress relaxation model to assess the response of a UPT tendon in a realistic UPT concrete building exposed to localized fire.

\section{OVERVIEW \& OBJECTIVES}

The fundamental issues under consideration in the current paper are the time $(t)$, temperature, $(T)$, stress $(\sigma)$, strength $\left(f_{p u}\right)$ interdependencies of cold-formed prestressing tendons, which can lead to irrecoverable prestress losses and/or premature tendon rupture during fire. The treatment herein is based on the interaction of stress relaxation from irreversible high temperature creep, $\varepsilon_{c r}=f(t, T, \sigma)$, and reversible thermal expansion, $\varepsilon_{T}=f(T)$ with the tendon's strength degradation, $f_{p s}=f(T)$, at high temperature.

To understand the implications of these interactions, a combination of experiments and numerical modelling has been conducted. Prior to performing defensible full-structure modelling of UPT buildings it is crucial that the transient high temperature stress relaxation response of the tendons be accurately understood and modelled; this is the core objective of the current study. To serve this goal, 19 isolated, prestressed UPT tendons were subjected to various localized transient heating scenarios and their temperatures and stress levels were continuously monitored. In this way, data were obtained which can allow the time-temperaturestress-strength interdependencies under localized heating to be more accurately modelled for any assumed tendon heating scenario (spatial or temporal). The model which has been developed by the authors for the prediction of transient thermal creep of cold-drawn prestressing has been partially validated previously by the authors $[28,29]$. The model is capable of treating any transient heating and cooling regime for any tendon length, heated length, tendon profile, and initial prestress level. Further validation and application is provided in the current two-part paper to allow assessment of high temperature tendon stress variation (or rupture) due to localized heating. The model is described in detail, as are its specific applications for assessing the potential implications of localized heating on a realistic UPT concrete structure, in Part II of this paper.

\section{EXPERIMENTAL PROGRAM}

The response of a UPT structural concrete element in fire is influenced by a host of interrelated factors. As already noted, the most important of these factors in ensuring adequate structural fire resistance are: (1) tendon rupture occurring as a consequence of localized heating, which has been widely observed both in real buildings and in standard fire tests on UPT elements; and (2) concrete cover spalling, which remains poorly 
understood and difficult to predict. The first of these issues is experimentally examined herein using a series of large-scale prestress relaxation tests on locally heated steel prestressing tendons - the second is studied through subsequent modelling exercises in Part II of this paper.

To investigate the stress-strength-temperature-time interdependencies of locally heated, stressed, unbonded, and restrained prestressing tendons of realistic length and parabolic tendon profile, a series of transient high temperature stress relaxation tests were conducted using a "Strongback" testing frame with an integrated custom tube furnace placed at mid-span (this is shown schematically in Figure 1).

The Strongback frame was specifically designed to simulate the conditions found within a typical UPT concrete slab [30]. Cold-drawn steel prestressing tendons with a total length of 18.3 metres were stressed against the Strongback frame, and a tube furnace with heating length of $610 \mathrm{~mm}$ was installed at mid-span. The tendon was mounted in a guide channel which was attached to parabolic profile plates welded to the top flange of a large steel plate girder. Bearing plates were added at both ends to accommodate anchorages, load cells and jacking of the tendon. Plastic sheathing was installed over the length of the guide channel to simulate the frictional conditions experienced by real UPT tendons. Individual seven-wire No. $13\left(99 \mathrm{~mm}^{2}\right.$ nominal cross sectional area) low relaxation prestressing steel strands of Grade $1860 \mathrm{MPa}$ were stressed in the Strongback frame to between $50 \%$ and $60 \%$ of their design ultimate strength. This represents a realistic in service prestress condition for a typical UPT structure after time-dependent losses have accumulated [1]. Once stressed, the tendons were locally heated, following one of a number of prescribed heating and cooling regimes, while their stress levels were continually monitored. The tendons were therefore heated over about $3.3 \%$ of their total length.

Eleven independent tests were performed using the Strongback frame. Selected testing details and results are given in Table 1. Also included in Table 1 are the results of eight similar tests performed previously by MacLean [31] using the same tube furnace and stress range, but with a shorter overall tendon length (resulting in a larger heated length ratio of about 11\%). The 11 new Strongback experiments presented herein were nearly identical (in ramp, soak, and cooling methodology) to those performed by MacLean [31] but used a more realistic total tendon length and hence had a smaller heated length ratio. These two heated length ratios allow a comparison of the behaviour of tendons under different localized heating scenarios and a better understanding of the effects of localized heating on stress relaxation and tendon rupture.

Each test consisted of stressing operations followed by three temperature exposure phases. For the stressing operations, the dead end of the strand was passed through a centre-hole load cell and secured within standard prestressing chucks. The live end of the specimen was stressed using a centre-hole hydraulic jack and standard chucks, also incorporating a centre-hole load cell. Once the appropriate load, approximately 100 $\mathrm{kN}$ in the current study, was achieved, the strand was locked off against the stressing frame using a different chuck and load cell assembly. This second assembly was equipped with a threaded expansion cylinder such that final prestress adjustments could be made manually after all seating losses had occurred. Prestress load levels were monitored for $24 \mathrm{hrs}$ before final adjustments were made to ensure that short term losses had occurred prior to heating and would not influence the testing results. The prestress prior to heat treatment for all specimens varied between $971 \mathrm{MPa}(52 \%$ of ultimate) to $1036 \mathrm{MPa}$ (55\% of ultimate), except for a single test intentionally performed with a target initial prestress of 600MPa.

Once tendons were stressed in the Strongback frame, the first temperature phase was an increasing temperature ramp at a constant rate of $10^{\circ} \mathrm{C} / \mathrm{min}$ (with two exceptions noted below) to a predefined temperature set-point between $200^{\circ} \mathrm{C}$ and $700^{\circ} \mathrm{C}$. This ramp rate was chosen to be approximately representative of a heating rate to be expected for a typical UPT tendon within a concrete structure subjected to a Standard Fire (and assuming no cover spalling), and is also consistent with prior testing available in the literature. The second phase consisted of a soak period of 90min at the set-point temperature. This was selected to be approximately representative of typical prescriptive North American fire resistance ratings for restrained UPT floor systems with $19 \mathrm{~mm}$ or more of clear concrete cover to the prestressed reinforcement [28,32]. This soak phase allowed for direct observation of the (approximately) steady-state temperature dependency of creep deformation. Finally, the third phase consisted of slow cooling (in air) to ambient temperature; this enabled investigation of the residual/recoverable prestress after transient localized heating.

Figure 2 shows the instrumentation used during the Strongback testing. Temperatures on the tendon were monitored by nine thermocouples placed along its length. Strains on the tendon were monitored using bonded foil gauges at two locations: one adjacent to the live end load cell, which was used to verify prestress readings; and the other outside the furnace near midspan, which was used to provide an indication of the importance of frictional effects along the length of the parabolically draped tendon. While some tests used 
additional bonded strain gauges to monitor frictional effects across the entire tendon length [33], it was found that frictional effects were negligible.

It must be emphasized that the experiments presented in the current paper consider only the response of a restrained prestressing steel tendon. Neither the potential impacts of the response of the surrounding structure nor of the imposed loads on tendon stress levels during fire are directly considered. In real UPT structures, applied loads, self weight, thermal deformations (elongation of the structure, thermal bowing), continuity, restraint, membrane actions (both compressive and tensile), discrete cracking, and shear failure modes are all likely to influence the response of continuous multiple-bay concrete structures in fire [28]. As previously noted, the aim in the current study is first to understand the behaviour of cold-drawn steel prestressing tendons under transient localized heating - a prerequisite to defensibly modelling real UPT structures in real fires.

\section{TEST RESULTS}

The results of the 11 high temperature transient prestress relaxation tests performed using the Strongback frame are presented in this paper (tests 1 to 11 in Table 1). Gales et al. [29] have previously used the results of tests 1 to 9 to verify the predictions of their aforementioned computational stress relaxation algorithm which explicitly accounts for creep deformations [28] and have shown reasonable agreement and trend behaviour (see Part II of this paper). The results of the eight similar tests by MacLean [31] are included in Table 1 for comparison (tests 12 to 19). Various parameters were varied amongst the tests shown in Table 1, including:

1) the heated length ratio, $3.3 \%$ or $11.4 \%$;

2) the initial targeted prestress level, $600 \mathrm{MPa}$ or $1000 \mathrm{MPa}$ (default);

3) the target soak temperature, between $200^{\circ} \mathrm{C}$ and $700^{\circ} \mathrm{C}$;

4) the soak duration, $5 \mathrm{~min}, 45 \mathrm{~min}$, or $90 \mathrm{~min}$ (default); and

5) the heating ramp rate, $2^{\circ} \mathrm{C} / \mathrm{min}, 10^{\circ} \mathrm{C} / \mathrm{min}$ (default), or $30^{\circ} \mathrm{C} / \mathrm{min}$.

It was found for all testing configurations that stress relaxation was time, temperature, and stress dependent indicating a clear influence of irrecoverable creep deformation at temperatures above about $300^{\circ} \mathrm{C}$. The effects of the respective parameters are discussed below.

\subsection{Heated Length Ratio}

Figure 3 shows the effect of the heated length ratio on the variation of tendon stress with heating by comparing tests performed by MacLean at $11.4 \%$ heated length [31] and Gales at 3.3\% heated length [33] for a $10^{\circ} \mathrm{C} / \mathrm{min}$ ramp, a hold of 90 minutes at $400^{\circ} \mathrm{C}$, and passive cooling to ambient. The figure shows that the longer heated length ratio results in greater overall prestress relaxation, but also shows that more prestress is recovered on cooling. These differences in behaviour are due to the fact that the longer heated length ratio experiences proportionally more thermal expansion, which means that the stress reduced more quickly during heating. A longer heated length ratio is thus less likely to experience a situation in which the tendon stress would exceed its strength (i.e. less likely to experience premature tendon rupture). An important consequence of this is that the critical temperature for rupture of an unbonded prestressing tendon depends to some extent on its heated length ratio, rather than being a single temperature as is assumed in all currently available design documents (e.g. [20,32]). Figure 3 also shows considerable irrecoverable reductions in prestress which persist after cooling; this is important for post-fire evaluation of UPT structures.

\subsection{Initial Prestress Level}

Only a single test (Test 5 in Table 1) was performed with a target initial prestress level other than 1000MPa. This test had an initial prestress level of $600 \mathrm{MPa}$, a heated length ratio of $3.3 \%$, and a soak phase of 90 minutes at $400^{\circ} \mathrm{C}$ - it was performed to investigate the performance of the computational model at tendon stress levels for which the creep parameters used in the model are available in the literature. This was necessary because some of the key input parameters in the computational creep model are available from tests with stress levels only up to $690 \mathrm{MPa}$ (for Grade 1720 prestressing steel), and the tests at $1000 \mathrm{MPa}$ initial prestress required these parameters to be extrapolated from the available data (see Part II of this paper). The model showed a maximum 3\% error between the experimental recorded and predicted results.

In comparison with tests 3 and 4, Test 5 shows the strong stress dependency of creep at elevated temperature, as it demonstrates only about $30 \mathrm{MPa}$ (Table 1) of irrecoverable prestress after cooling as compared with about $142 \mathrm{MPa}$ and $178 \mathrm{MPa}$ for tests 3 and 4 with higher initial prestress levels. This also 
demonstrates that creep is less important for mild steel reinforcement than for prestressed reinforcement during fire, since the stress in mild steel reinforcing bars is likely to be less than 200MPa under service loads.

\subsection{Soak Temperature}

Figure 4 shows the effect of soak temperature for tests with heated length ratios of $3.3 \%$ and $11.4 \%$, a ramp rate of $10^{\circ} \mathrm{C} / \mathrm{min}$, a soak temperature of $400^{\circ} \mathrm{C}$, and a soak time of $90 \mathrm{~min}$. Included in the figure are lines showing the tendon stress at the start of the soak period, the end of the soak period, and after cooling to ambient temperature. Figure 4(a) shows the effect of soak temperature for strands tested at a heated length ratio of $3.3 \%$. Test 10 , with a soak temperature of $500^{\circ} \mathrm{C}$, ruptured shortly after reaching the soak temperature, and Test 11 , with a soak temperature of $700^{\circ} \mathrm{C}$, never reached its soak temperature and ruptured at a temperature of $524^{\circ} \mathrm{C}$. Figure 4(b) shows the effect of soak temperature for strands tested at a heated length ratio of $11.4 \%$; in this case all tendons survived all phases of heating and cooling without experiencing rupture.

It is clear from Figure 4 that reductions in tendon stress are apparent at temperatures above $300^{\circ} \mathrm{C}$, and that the effect of creep deformation becomes important between $300^{\circ} \mathrm{C}$ and $400^{\circ} \mathrm{C}$. Figure 5 shows the irrecoverable prestress loss exhibited for tendons with different soak temperatures and heated length ratios. The acceleration of irrecoverable prestress loss at temperatures above $300^{\circ} \mathrm{C}$ is clear.

\subsection{Soak Duration}

Figure 6 shows the effect of soak duration for tendons with 3.3\% and $11.4 \%$ heated length ratios, again by comparing tendon stress levels at the start and end of the soak period and after cooling to room temperature. This figure shows the time dependency of creep strains, since longer soak times tend to cause lower residual prestress values and larger prestress changes during the soak period (which can be considered a steady-state "secondary" creep phase at elevated temperature). This is particularly evident by comparing the "start of soak" and "end of soak" trends. Figure 6 demonstrates that the time dependency of creep strain is significant within minutes and occurs at temperatures well below those considered the critical temperature of prestressing steel in North America (i.e. $426^{\circ} \mathrm{C}$ ) [32].

\subsection{Heating Ramp Rate}

Tests 8,4 , and 9 were identical but for the fact that they used heating ramp rates of $2^{\circ} \mathrm{C} / \mathrm{min}, 10^{\circ} \mathrm{C} / \mathrm{min}$, and $30^{\circ} \mathrm{C} / \mathrm{min}$, respectively. On the basis of these tests the heating ramp rate appears not to play a critical role within the range tested and up to a soak temperature of $400^{\circ} \mathrm{C}$; the prestress reductions during the ramp phase showed no obvious trend and were similar to each other within $4 \%$. It is expected, however, that ramp rate would play a more important role at temperatures between $400^{\circ} \mathrm{C}$ and $500^{\circ} \mathrm{C}$, where creep straining accelerates rapidly. It is worth noting that the observation that ramp rate does not appear to be significant up to $400^{\circ} \mathrm{C}$ lends credence to the Eurocode's [20] implicit inclusion of creep in defining the stress-strain characteristics of prestressing steel at elevated temperature, but only if tendon temperatures are limited to less than $400^{\circ} \mathrm{C}$ (actually the stated limit is $350^{\circ} \mathrm{C}$ for UPT tendons in EN 1992-1-2 [20], but in the International Building Code (IBC) it is $426^{\circ} \mathrm{C}[21,32]$ which seems hard to justify on the basis of the data presented herein).

\subsection{Repeatability}

Acceptable repeatability was shown at both heated length ratios (i.e. tests 3 and 4 at $11.4 \%$ heated length and tests 14 and 15 at $3.3 \%$ heated length). In both cases, identical tests with a $90 \mathrm{~min}$ soak at $400^{\circ} \mathrm{C}$ showed negligible differences $(<10 \mathrm{MPa})$ in tendon stress during all heating phases.

\subsection{Tendon Rupture}

Sudden, violent tendon rupture was observed in two tests (10 and 11) both of which were performed in the Strongback frame with a heated length ratio of 3.3\%. While at first glance 3.3\% seems an unrealistically small heated length ratio, the fact that that UPT tendons in real structures have parabolic profiles and may be continuous over multiple bays with a total length of more than $70 \mathrm{~m}$ between anchorages [34] means that 3.3\% is actually a perfectly credible (even likely) heating scenario in a real building. Tendon rupture will cause immediate reductions in both the flexural and shear capacity of a floor plate across multiple bays of a structure, and would also prevent the mobilization of a tensile membrane mechanism in cases where no additional bonded reinforcement is provided in sagging moment regions, as is permitted by many design 
codes [e.g. 35-37] under certain conditions. This is particularly concerning for structures using banded multistrand UPT tendons, where four or more tendons could be lost in rapid succession with little warning.

Figure 7 compares observed tendon stress versus heated region temperature profiles for tests 10 and 11 (3.3\% heated length ratio) and Test 18 (11.4\% heated length ratio). The Eurocode strength reduction curve for prestressing steel is also shown (from Table 3.3 of EN 1992-1-2 [20]) along with the less conservative tendon strength reduction curve suggested by Abrams and Cruz [38] which appears to be the basis for much of the existing North American prescriptive design guidance. Test 10 experienced tendon rupture at $501^{\circ} \mathrm{C}$ (two minutes into the targeted $500^{\circ} \mathrm{C}$ soak phase) and Test 11 ruptured at $524^{\circ} \mathrm{C}$ (during the ramp phase). MacLean's experiments with an $11.4 \%$ heated length ratio did not experience tendon rupture for the same temperature exposures (Tests 18 and 19 in Table 1). This is because the larger heated length used in MacLean's test had larger recoverable prestress relaxation due to thermal expansion. This reduced the stress in the tendon so that the instantaneous tendon stress did not exceed the tendon strength and failure was avoided. Whether this would occur in a real building would depend on the ability of the tendons to shed gravity loads to the bonded reinforcement (if present), and on the deformations of the structure during heating. However, it is clear that tendons with shorter heated length ratios experience less thermal expansion in proportion to the total unbonded length, and that tendon rupture is therefore considerably more likely.

The Eurocode's [20] temperature strength reduction formulae are thought to represent a conservative lower bound for predicting the tensile strength of prestressing steel at elevated temperature [39], and this is evident as being the case for the tests shown in Figure 7 where the experimental stress profiles cross the Eurocode strength curve at temperature as much as $100^{\circ} \mathrm{C}$ below the point where rupture was observed. In the case of MacLean's test, where rupture was not observed, the Eurocode's curve predicts failure at a temperature about $120^{\circ} \mathrm{C}$ less than was actually experienced by the tendon (prior to or without rupture). The Eurocode's strength reductions predict tendon rupture for an additional six of the 11 Strongback tests (excluding tests 1,2 and 5) and six of MacLean's eight tests (excluding tests 12 and 13) where no ruptures were observed. This confirms the conservative nature of the Eurocode recommendations, as previously noted by Ellobody and Bailey [40], although it also shows that this conservatism is reduced as the heated length ratio decreases and tendon rupture becomes more likely. The less conservative Abrams and Cruz strength reduction curve [38] shows a small degree of conservatism in predicting tendon rupture with these tests.

Figure 7 also shows the cooling phase of MacLean's $500^{\circ} \mathrm{C}$ test (in which rupture did not occur) again the important irrecoverability of tendon stress on cooling is clear.

The above discussion raises a number of issues related to the colloquial distinction between creep straining and mechanical plastic straining (yielding), particularly at elevated temperature. As the temperature of a stressed tendon increases and its yield strength and elastic modulus decrease, the distinction between yielding and creep deformation becomes blurred and the classical definitions of these strains lose meaning. What is therefore necessary for defensible computational modelling at temperatures and stress levels where creep and yielding are so closely intertwined is an ability to rationally account for all the relevant physical processes, rather than trying to inherently account for creep by introducing blanket conservatisms - which may not actually be universally conservative, as is shown in Part II.

\section{CONCLUSIONS}

Performance based structural fire design codes are currently in the process of being developed and refined across the world. With this in mind a fundamental understanding of various aspects of the real behaviour of continuous UPT concrete slab structures (both flat plates and other types of UPT structures), when subjected to elevated temperatures, is needed. Available mechanical property reduction models for prestressing steel, which 'implicitly' account for high temperature creep, cannot possibly capture the time-dependency of creep deformation under transient heating conditions as would occur in a real fire. The consequences of this inability for computational structural modelling in support of performance based structural fire engineering remain unknown.

The experiments presented in this paper have clearly illustrated the time-temperature-stress-strength interdependencies affecting UPT tendons subjected to transient localized heating. They have demonstrated that the effects of creep deformation become important at temperatures between $300^{\circ} \mathrm{C}$ and $400^{\circ} \mathrm{C}$, and that creep accelerates rapidly at temperatures above about $350^{\circ} \mathrm{C}$. Explicit consideration of creep strains is thus important for structural fire modelling at temperatures well below the $426^{\circ} \mathrm{C}$ critical temperature of prestressing steel currently assumed in North American codes [21, 32], and in some cases at temperature below the $350^{\circ} \mathrm{C}$ critical temperature imposed by Eurocode 2 [20]. The tests additionally showed that: 
- longer heated length ratios resulted in greater overall prestress relaxation, but also in greater prestress recovery on cooling.

- tendons with shorter heated length ratios experienced less thermal expansion in proportion to their total unbonded length, so that tendon rupture was considerably more likely under localized heating.

The above observations compellingly suggest that the critical temperature for UPT tendons depends on the tendons' heated length ratio, with smaller heated lengths having lower critical temperatures (with respect to tendon rupture).

\section{ACKNOWLEDGEMENTS}

We gratefully acknowledge the support of the Ove Arup Foundation, the Royal Academy of Engineering, the University of Edinburgh, and Natural Sciences and Engineering Research Council of Canada. We would also like to thank Kevin MacLean (Reid Jones Christoffersen, Toronto, Canada) and Dr Colin MacDougall (Queen's University, Canada) for their earlier contributions to this work.

\section{REFERENCES}

1. Martin, L. and Purkiss, J., Concrete Design to EN 1992, Butterworth-Heinemann, $2^{\text {nd }}$ Ed, 2006.

2. Post, N. and Korman, R., Implosion Spares foundations, Engineering News record, June 12 2000, 12-13.

3. Iwankiw, N. Beyler, C. and Beitel, J., Testing Needs for Advancement of Structural Fire Engineering, Fifth International Conference on Structures in Fire, Singapore, 2008, 334-343.

4. Bailey, C. and Ellobody, E., Comparison of Unbonded and Bonded Post-Tensioned Concrete Slabs under fire Conditions, The Structural Engineer, October 2009, 87(19), 23-31.

5. Troxell, G.E., Fire Resistance of a Prestressed Concrete Floor Panel, Journal of the American Concrete Institute, August 1959, 97-105.

6. Troxell, G.E., Fire Test of Six inch Deep Prestressed Concrete Flat slabs, Fire Prevention Research Institute, Gardena, Calif., December 1959.

7. Underwriters Laboratories, Report on Prestressed Pre-tensioned Concrete Inverted Tee Beams and Report on Prestressed Concrete Inverted Tee Beams Post-Tensioned, R4123-12A, Underwriters' Laboratories Inc, USA, 1966.

8. Underwriters Laboratories, Report on Unbonded Post-Tensioned Prestressed Reinforced Concrete Flat Plate Floor with Expanded Shale Aggregate, PCI Journal, 1968, 45-56.

9. Gustaferro, H. Abrams, M. and Salse, E., Fire Resistance of Prestressed Concrete Beams Study C: Structural Behaviour During Fire Tests, PCA Research and Development Bulletin, 1971, 29pp.

10. Van Heberghen, P. and Van Damme, M., Fire Resistance of Post-Tensioned Continuous Flat Floor Slabs with Unbonded Tendons, FIP notes, 1983, 3-11.

11. Zheng, W. and Hou, X., Experiment and Analysis on the Mechanical Behaviour of PC Simply Supported Slabs Subjected to Fire, Advances in Structural Engineering, 2008, 11(1) 71-89.

12. Bailey, C. and Ellobody, E., Fire Tests on Unbonded Post-Tensioned One-way Concrete Slabs, Magazine of Concrete Research, 2009, 61(1), 67-76.

13. Kelly, F. and Purkiss, J., Reinforced Concrete Structures in Fire: A Review of Current Rules, The Structural Engineer, 2008, 86(19), 33-39.

14. Gales, J., Bisby, L. and Gillie, M., Unbonded Post Tensioned Concrete in Fire: A Review of Data from Furnace Tests and Real Fires, accepted for publication in Fire Safety Journal, December 2010.

15. Troxell, G.E., Prestressed lift slabs withstand fire, ASCE Civil Engineer, September 1965, 64-66.

16. Lukkunaprasit, P., Unbonded Post-Tensioned Concrete Flat plates under 5-hours of fire, $11^{\text {th }}$ FIP congress in Hamburg Germany, 1990, S61-S64.

17. Barth, F. and Aalami, B., Controlled Demolition of an Unbonded Post-Tensioned Concrete Slab, PTI special report, 1992, $34 \mathrm{pp}$.

18. Sarkkinen, D., Fire Damaged Post-tensioned Slabs, Structure Magazine, June 2006, 32-34.

19. Stern, I, Restoration of Long Span Plate Post-Tensioned with Unbonded Tendons - after fire, Lecture given at the 2002 fib Congress, Osaka, Japan. Information on web; http://www.yde.co.il/ accessed December $22^{\text {nd }} 2009$.

20. British Standards Institution, Eurocode 2: Design of Concrete Structures, Parts 1-2: General rulesStructural fire design, ENV 1992-1-2, European Committee for standardization, Brussels, 2004.

21. IBC, International Building Code, International Code Council, USA, 2009. 
22. NIST, NCSTAR 1A: Final Report on the Collapse of World Trade Center Building 7, National Institute of Standards and Technology, Gaithersburg, USA, 2008, 130pp.

23. Shipp, M. Fraser-Mitchell, J. Chitty, R. Cullinan, R. Crowder, D. and Clark, P., Fire Spread in Car Parks; a summary of the CLG/BRE Research programme findings, BRE Global Limited, Bucknails Lane, Watford, Hertfordshire, UK, 2009, 15 pp.

24. Stern-Gottfried, J. Rein, G. Bisby, L. and Torero, J., Experimental Review of Homogeneous Temperature Assumption in Post-Flashover Compartment Fires, Fire Safety Journal, 2010, 45(4), 249-261.

25. Stern-Gottfried, J. Rein, G. and Torero, J., Travel Guide: A Newly developed methodology, based on concept of 'travelling fires' in large enclosures, will assist with Structural fire analysis, Fire Risk Management, November 2009, 12-16.

26. Bailey, C. and Ellobody, E., Whole-Building Behaviour of Bonded Post-Tensioned Concrete Floor Plates Exposed to Fire, Engineering Structures, 2009, 31, 1800-1810.

27. Ellobody, E. Bailey, C, Modelling of Unbonded Post-Tensioned Concrete Slabs under Fire Conditions, Fire Safety Journal, 2009, 44, 159-167.

28. Gales, J. Bisby, L. MacDougall, C. and MacLean, K., Transient High-Temperature Stress Relaxation of Prestressing Tendons in Unbonded Construction, Fire Safety Journal, 2009, 44, 570-579.

29. Gales, J. Bisby, L. and MacDougall, C., Fire Induced Transient Creep Causing Stress Relaxation and Tendon Rupture in Unbonded Post-Tensioned Structures: Experiments and Modelling, in: Kodur, V. and Franssen, J.M., ed., Proceedings from the Sixth International Conference on Structures in Fire, DEStech Publications, Lancester Michigan, 2010, 727-734.

30. MacDougall, C., and Bartlett, F.M., Tests of Unbonded Seven-Wire Tendon with Broken Outer Wires, ACI Structural Journal, 2003, 100(5), 581-588.

31. MacLean, K., Post-fire Assessment of Unbonded Post-Tensioned Concrete Slabs: Strand Deterioration and Prestress Loss, M.Sc thesis, Department of Civil Engineering, Queen's University, Kingston, ON, Canada, 2007.

32. PTI., Post-Tensioning Manual-Sixth Edition, Post-Tensioning Institute, Phoenix, AZ, 2006.

33. Gales, J., Transient High-temperature Prestress Relaxation of Unbonded Prestressing Tendons for use in concrete slabs, M.Sc. thesis, Department of Civil Engineering, Queen's University, Kingston, On, Canada, 2009.

34. Taranath, B.S., Reinforced Concrete Design of Tall Buildings, CRC Press, Taylor and Francis, 2010.

35. British Standards Institution, Eurocode 2, Design of concrete structures -Part 1-1: General rules and rules for buildings, BSI, London, 2002.

36. ACI committee 318., Building Code Requirements for Structural Concrete, Rep. No. ACI 318-08, American Concrete Institute, Farmington Hills, MI, 2008.

37. Canadian Standards Association., CAN/CSA A23.3-04: Design of Concrete Structures, CSA, Ottawa, ON, 2004.

38. Abrams, M.S. and Cruz, C., The Behaviour at High Temperature of Steel Strand for Prestressed Concrete, Journal of PCA Research and Development Laboratories, September 1961, 3(3), 8-19.

39. Background documents to EN 1992-1-2 Eurocode 2: Design of concrete structures -Part 1-2: General rules - Structural fire design, European Committee for standardization, Brussels, July 2004.

40. Ellobody, E. and Bailey, C., Testing and Modelling of Bonded and Unbonded Post-Tensioned Concrete Slabs in Fire, Proceedings from the Fifth International Conference on Structures in Fire, Singapore, 2008, 392-405

41. MacLean, K. Bisby, L. and MacDougall, C., Post-fire Assessment of Unbonded Post-tensioned Slabs: Strand Deterioration and Prestress loss, ACI-SP255: Designing Concrete Structures for Fire Safety, American Concrete Institute, 2008, 10 pp. 
Table 1: Overview of transient, localized, high temperature relaxation tests performed by Gales [29] and MacLean $[31,41]$

\begin{tabular}{|c|c|c|c|c|c|c|c|c|c|}
\hline \multirow[b]{2}{*}{ Test \# $\#^{\mathrm{a}}$} & \multirow[b]{2}{*}{$\begin{array}{l}\text { Heated } \\
\text { length ratio } \\
(\%)\end{array}$} & \multicolumn{4}{|c|}{ Test setup } & \multicolumn{4}{|c|}{ Prestress levels } \\
\hline & & $\begin{array}{l}\text { Initial } \\
\text { prestress }^{b} \\
(\mathrm{MPa})\end{array}$ & $\begin{array}{c}\text { Target } \\
\text { soak temp } \\
\left({ }^{\circ} \mathrm{C}\right)\end{array}$ & $\begin{array}{l}\text { Soak } \\
\text { time } \\
(\min )\end{array}$ & $\begin{array}{l}\text { Ramp } \\
\text { rate } \\
\left({ }^{\circ} \mathrm{C} / \mathrm{min}\right)\end{array}$ & $\begin{array}{c}\text { Start } \\
\text { of soak } \\
(\mathrm{MPa})\end{array}$ & $\begin{array}{c}\text { End } \\
\text { of soak } \\
(\mathrm{MPa})\end{array}$ & $\begin{array}{l}\text { Residual } \\
\text { stress } \\
(\mathrm{MPa})\end{array}$ & $\begin{array}{c}\text { Irrecoverable } \\
\text { prestress } \\
(\mathrm{MPa})\end{array}$ \\
\hline \multicolumn{10}{|c|}{ Gales' Tests } \\
\hline 1 & 3 & 974 & 200 & 90 & 10 & 962 & 961 & 972 & 2 \\
\hline 2 & 3 & 971 & 300 & 90 & 10 & 945 & 941 & 953 & 18 \\
\hline 3 & 3 & 973 & 400 & 90 & 10 & 871 & 808 & 831 & 142 \\
\hline 4 & 3 & 1009 & 400 & 90 & 10 & 883 & 807 & 831 & 178 \\
\hline 5 & 3 & 599 & 400 & 90 & 10 & 558 & 549 & 569 & 30 \\
\hline 6 & 3 & 997 & 400 & 5 & 10 & 882 & 882 & 897 & 100 \\
\hline 7 & 3 & 1015 & 400 & 45 & 10 & 850 & 815 & 824 & 191 \\
\hline 8 & 3 & 1007 & 400 & 90 & 2 & 908 & 805 & 814 & 193 \\
\hline 9 & 3 & 1015 & 400 & 90 & 30 & 881 & 769 & 786 & 229 \\
\hline 10 & 3 & 997 & 500 & 2 & 10 & 663 & $-{ }^{d}$ & $--^{d}$ & $-{ }^{d}$ \\
\hline 11 & 3 & 983 & 700 & -- & 10 & $--^{d}$ & $--^{d}$ & $--^{d}$ & $--^{d}$ \\
\hline \multicolumn{10}{|c|}{ MacLean's Tests } \\
\hline 12 & 11 & 1002 & 200 & 90 & 10 & 953 & 947 & 993 & 9 \\
\hline 13 & 11 & 1006 & 300 & 90 & 10 & 922 & 896 & 972 & 34 \\
\hline 14 & 11 & 1001 & 400 & 90 & 10 & 800 & 648 & 762 & 239 \\
\hline 15 & 11 & 1014 & 400 & 90 & 10 & 821 & 663 & 775 & 239 \\
\hline 16 & 11 & 1022 & 400 & 45 & 10 & 817 & 697 & 812 & 210 \\
\hline 17 & 11 & 1036 & 400 & 5 & 10 & 832 & 771 & 875 & 161 \\
\hline 18 & 11 & 1003 & 500 & 90 & 10 & 497 & 245 & 388 & 615 \\
\hline 19 & 11 & 975 & 700 & 90 & 10 & 42 & 3 & 140 & 835 \\
\hline
\end{tabular}

${ }^{\mathrm{a}}$ For Tests 12-19, details can be found in MacLean et al. [41]

${ }^{\mathrm{b}}$ The target initial prestress was $1000 \mathrm{MPa}$ with exception of Test 5 in which it was $600 \mathrm{MPa}$

${ }^{\mathrm{c}}$ The maximum overshoot for tests $1-11$ was $1.5 \pm 2.0^{\circ} \mathrm{C}$ and tests $12-19$ was $5.6 \pm 3.6^{\circ} \mathrm{C}$

d Tendon rupture 




Figure 1: Strong back beam testing frame

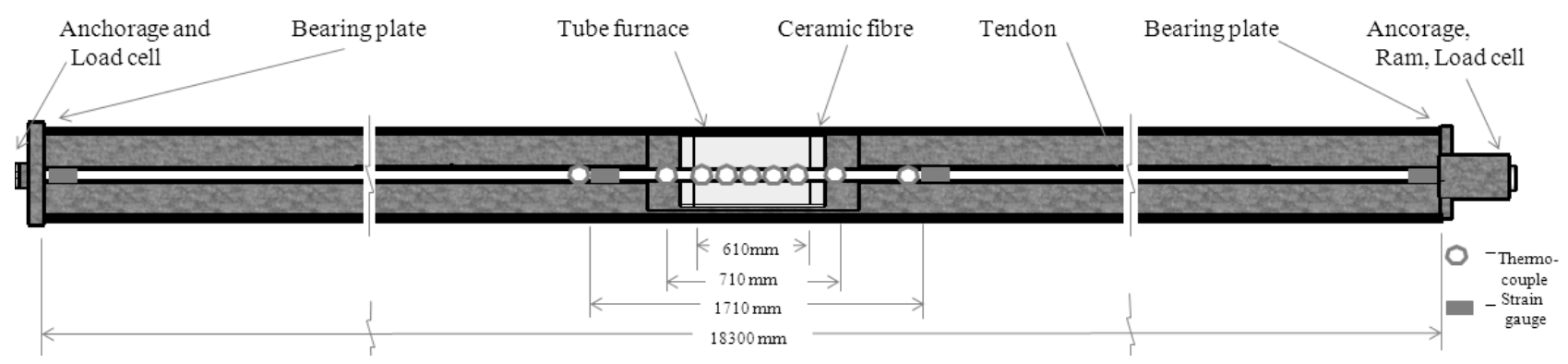

Figure 2: Schematic of strong back beam and instrumentation

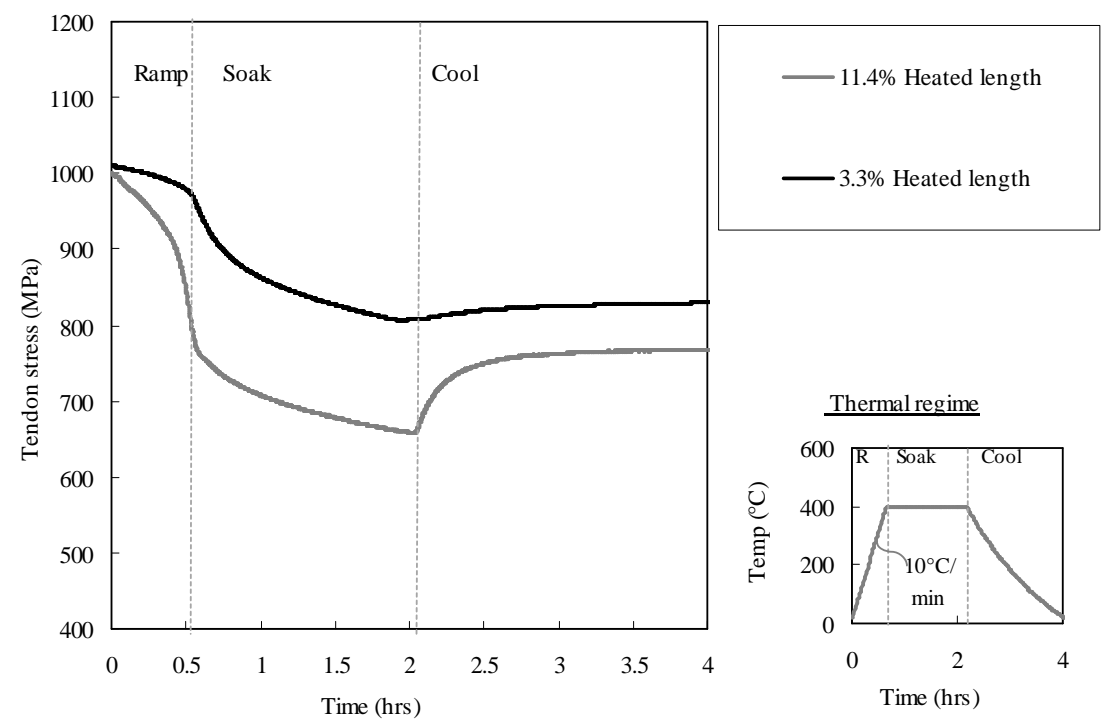

Figure 3: Measured variation of tendon stress for tendons with different heated length ratios heated to $400^{\circ} \mathrm{C}$ for $90 \mathrm{mins}$ and subsequently cooled to room temperature 
(a)

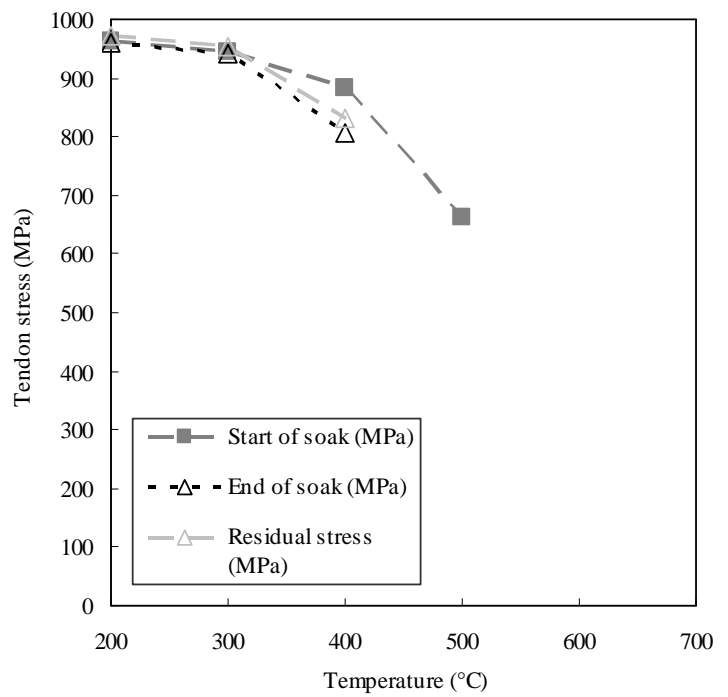

(b)

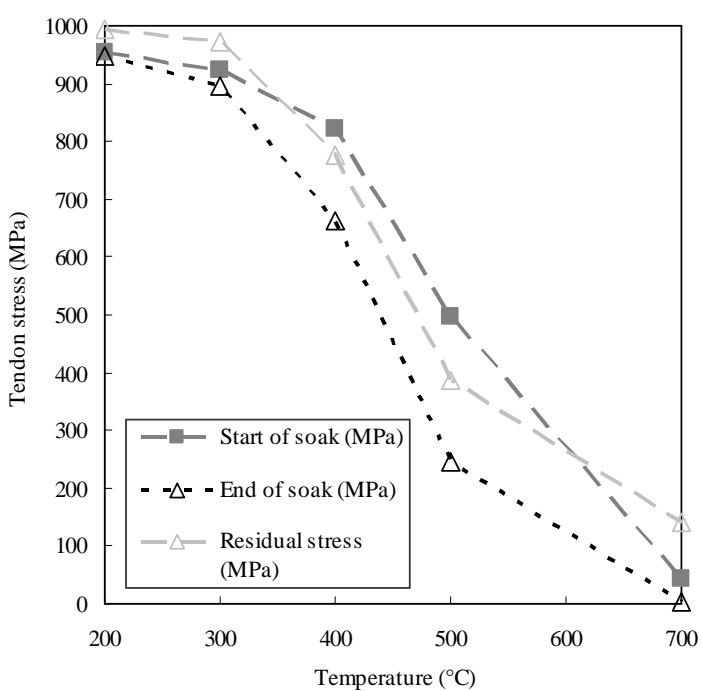

Figure 4: Comparison of experimentally observed variation in tendon stress for different soak temperatures: (a) 3.3\% heated length ratio (b) $11.4 \%$ heated length ratio 


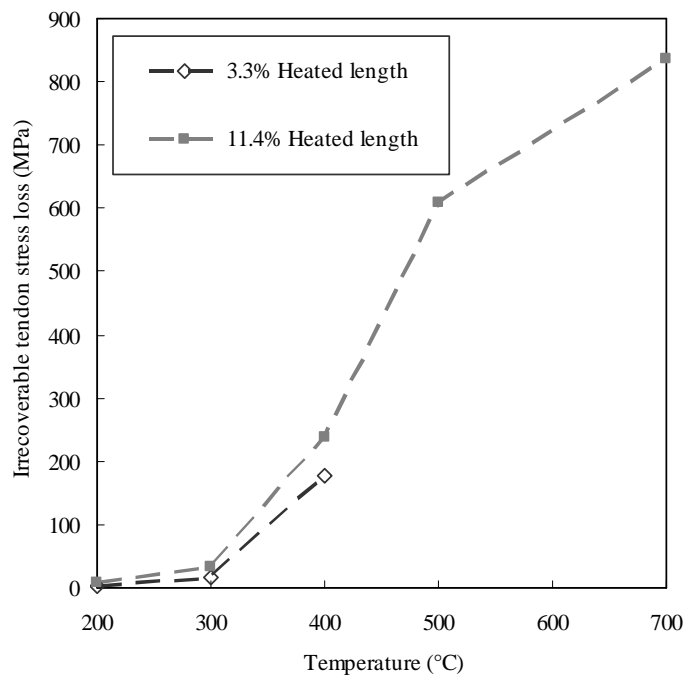

Figure 5: Experimentally measured irrecoverable tendon stress loss for different heated length (a)

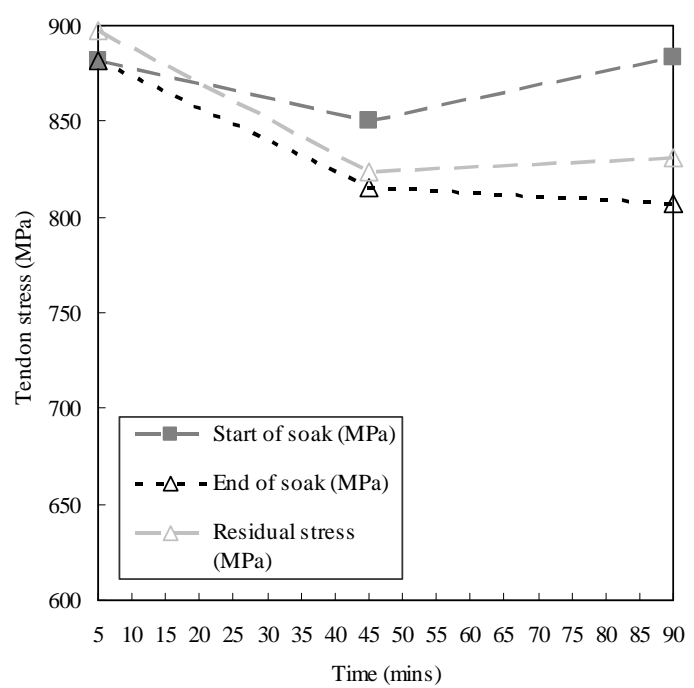

(b)



Figure 6: Experimentally observed variation of tendon stress for different soak durations: (a) 3.3\% heated length ratio and (b) $11.4 \%$ heated length ratio 

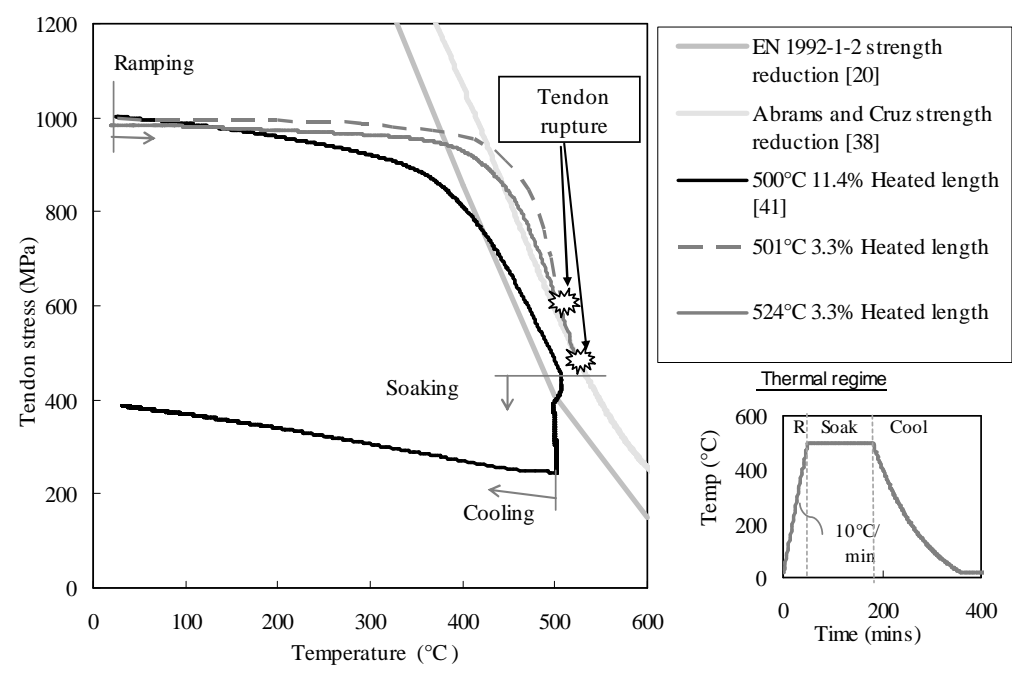

Figure 7: Strength-stress-temperature-time dependency of tendon stress levels during transient high temperature relaxation tests of various configurations 